\title{
COVID-19 and Climate Change
}

\author{
Aahil Damani \\ MBBS Student, Guys Kings \& St Thomas's Medical School, London, UK \\ Music Society President 19/20 \\ aahil.damani@kcl.ac.uk
}

Key words

Climate change, COVID-19

\begin{abstract}
Climate change has been a focal issue for centuries, but even more so in the last decade, with much focus in recent months on the Venetian natural hazards and the Australian bushfires; visible events that were close to home; in the West. However, fast forward a few months, we now find ourselves in an unimaginable and unprecedented situation; the COVID-19 pandemic, a Public Health Emergency of International Concern (PHEIC) as well as an economic crisis, and climate change could not be more relevant.
\end{abstract}

Cite as: Damani, A. (2020) COVID-19 and Climate Change. Sushruta 13(2): pre-print v1; ePUB 03.05.2020 DOI: $10.38192 / 13.2 .10$

There has been an exponential rise in the number of cases and deaths, loss of jobs, increase in debt, panic buying as well as a sense of fear spreading across the globe. However, many will have seen or heard stories of fish appearing in the Venetian waters (1), or the images of the Chinese skies appearing clear and blue for the first time in a while. So how does climate change fit into the picture? The role climate change plays in COVID-19 is important and little attention has been paid to this. Whilst the number of studies are increasing exponentially, there is still a dearth of data on the topic. In this article, I hope to explore the different role climate plays in this pandemic. I will focus on 3 main aspects of the interrelationship between climate change and infectious diseases, with COVID-19 being the case study:

1. Effect of lockdown (secondary to the pandemic) on climate change

2. Effect of lockdown (secondary to the pandemic) on data collection of air pollution

3. Effect of the SARS-CoV-2 (virus) on individuals from areas with high air pollution

\section{1: Effect of lockdown (secondary to the pandemic) on climate change:}

Firstly, the pandemic has taken the world by such a storm, that healthcare systems are fearing for their capacity. Lockdown (or quarantine) is one very effective way to slow the transmission of the disease by limiting physical interactions between one and another; flattening the curve. Of course, this results in less travelling, working from home and fewer social interactions, all of which one would assume result in less air pollution. But is that actually making a difference to 
the climate? The peak of the pandemic coincided with the seasonal spring smog, which is the most polluted time of year due to the winds from Europe as well as fertilising plants and crops in the farmyard (2). In the Spring of 2014, the seasonal smog in the UK caused around 600 deaths (3). Although activities that contribute massively to air pollution have come to a grinding halt, this has been counteracted by other activities that have not ceased despite a lockdown: agriculture and wood burning to heat homes. This has contributed to the particle pollution numbers still being above what is considered a low air pollution banding (score of $<4$ on the 10-point Air Quality Index scale) (2).

In Venice, for example, the clarity of the water is not actually due to less air pollution but rather due to an "absence of motorised transport", according to Davide Tagliapetra, an environmental researcher (4). Which poses the question, with COVID-19 silencing the tourism and hospitality industry, could the pandemic enable us to pay closer attention to the interconnectedness of tourism on climate change and modify our attitudes towards tourism?

\section{Effect of lockdown (secondary to the pandemic) on data collection of air pollution}

Infectious disease outbreaks pose another problem; due to the rapid transmission, nature of the virus and the incubation period they often require suspected individuals displaying signs and symptoms of the virus to self-isolate and stay at home to prevent further spread. The impact on the workforce can be substantial and detrimental; Transport for London (TfL) reported a third of their employees were off work due to illness or self-isolating (5) and the National Health Service (NHS) reported a figure of 25\% (6). Whilst the exposure to the virus in these professional organisations vary, it would not be unreasonable to assume that similar trends are being observed in other sectors as hinted by a report by the London Air Quality Network. A reduced workforce; decrease in supply means there is a discrepancy in meeting the increased demand.

We have seen within the medical profession; the shortage of nurses and doctors is not one that can be simply addressed in an acute emergency such as this. The same can be said about the air control employees. These roles require training and tasks involve the utilisation of specific instrumentation (7) that certain individuals can use, making them difficult to replace with the knock-on effect is that invaluable data that may be compromised. For those unaffected and fit to work, unclear guidelines issued by the government make the advice open for interpretation. The constant changing of guidelines reflects the magnitude of unknown with regards to the virus. Whilst much attention has been paid to the pathophysiology of the virus, the difference in mortality between the two genders and the efficacy of outbreak control measures, it is inevitable that once the pandemic passes and the storm calms down, scientists and environmentalists will aim to draw comparisons between air pollution levels and hospital admissions due to COVID-19 by region. Which makes it paramount that accurate data concerning air quality is collected now.

\section{Effect of the SARS-CoV-2 (virus) on individuals from areas with high air pollution}


The correlation between major cities with high air pollution days and the number of COVID-19 cases would be an interesting one to study. Whilst confounding factors and other determinants play a role, with an upper respiratory disease such as Covid-19, the quality of air in the area in which someone lives is bound to have an impact on the pre-disposition to the severity of the disease. We have been told repeatedly, particularly in the initial stages of the outbreak where there were uncertainties about the condition, that the majority of those dying have preexisting conditions. Although the virus affects individuals of all ages, genders, ethnicities and does not discriminate, we do know that many of the pre-existing conditions such as asthma are exacerbated by air pollution (3, 8-11). Of course, correlation does not mean causation and factors such as socioeconomic factors and dense population play a part. Areas such as London make transmission of the virus both within the city and households more likely. But with the situation unfolding so rapidly and fast turnover-times, studies are already under away with Harvard university suggesting that areas with higher fine-particle pollution levels also saw mortality rates increase by approximately $15 \%$ (12). However, the study is still in its infancy and has not yet been peer-reviewed.

To conclude, all aspects of the biopsychosocial model are covered by the Covid-19 outbreak. The biological effects of the virus are evident with shortness of breath, coughing and classic signs of infection apparent for many of those affected. The social effects are also taking a toll on us; humans are social beings and the lockdown has proven to be difficult to become accustomed to, with what was initially 3 weeks and still in place for the foreseeable future. No doubt, both the biosocial factors impact the psychological emotions of anxiety, loneliness and helplessness. (13). Similarly, we can de-construct the 3 components of the biopsychosocial model and apply it to climate change:

- Biological: less air pollution is benefitting our health $\rightarrow$ those with pre-existing respiratory conditions such as asthma

- Social: Working from home results in less commuting $\rightarrow$ less pollution

- Psychological: The "one form of exercise a day" advice is being taken up by many and has allowed us to really appreciate nature and our surroundings more, in its purest and most tranquil form. This form of outdoor exercise also acts as an outlet for stress.

However, as tragic times often call for solidarity such as the inception of the NHS in 1948 following the World Wars, could we come out of the pandemic stronger than ever before and renew our commitment to climate change and air pollution? Could this be the catalyst and driver in making the 1-day traffic stop possible and help reduce the seasonal spring smog? Could this eliminate unnecessary travel, encouraging working from home? Could this reduce unnecessary flights across the globe that emit more energy than anything else? With cities such as Milan already pledging to reduce vehicle use in the post-lockdown era (14), let us hope that other cities will follow in its footsteps. Only time can tell.

\section{References}

1. Without tourism, Venice is in the clear [Internet]. Sustainability-times.com. 2020 [cited 2 May 2020]. Available from: https://www.sustainability-times.com/cleancities/without-tourism-venice-is-in-the-clear/ 
2. Fuller G. Lockdown eases seasonal smog - but less than expected [Internet]. the Guardian. 2020 [cited 1 May 2020]. Available from: https://www.theguardian.com/environment/2020/apr/02/lockdown-eases-seasonalsmog-pollution

3. Macintyre H, Heaviside C, Neal L, Agnew P, Thornes J, Vardoulakis S. Mortality and emergency hospitalizations associated with atmospheric particulate matter episodes across the UK in spring 2014. Environment International. 2016;97:108-116.

4. Brunton J. 'Nature is taking back Venice': wildlife returns to tourist-free city [Internet]. the Guardian. 2020 [cited 1 May 2020]. Available from: https://www.theguardian.com/environment/2020/mar/20/nature-is-taking-backvenice-wildlife-returns-to-tourist-free-city\#maincontent

5. Khan S. Coronavirus (COVID-19) news feed [Internet]. London.gov.uk. 2020 [cited 1 May 2020]. Available from: https://www.london.gov.uk/updates/news-feed

6. Andrew Goddard, President of the Royal College of Physicians. 2020.

7. Fuller G. COVID-19: Air pollution during lockdown [Internet]. Kcl.ac.uk. 2020 [cited 1 May 2020]. Available from: https://www.kcl.ac.uk/covid-19-air-pollution-duringlockdown

8. Carrington D. Preliminary study links air pollution to coronavirus deaths in England [Internet]. the Guardian. 2020 [cited 1 May 2020]. Available from: https://www.theguardian.com/environment/2020/apr/21/preliminary-study-links-airpollution-to-coronavirus-deaths-in-england

9. Carrington D. Air pollution linked to far higher Covid-19 death rates, study finds [Internet]. the Guardian. 2020 [cited 1 May 2020]. Available from: https://www.theguardian.com/environment/2020/apr/07/air-pollution-linked-to-farhigher-covid-19-death-rates-study-finds

10. Walton $H$. Higher air pollution days trigger cardiac arrests and hospitalisations [Internet]. Kcl.ac.uk. 2019 [cited 1 May 2020]. Available from: https://www.kcl.ac.uk/news/higher-air-pollution-days-trigger-cardiac-arrests-andhospitalisations

11. Khadka N. Air pollution linked to raised Covid-19 death risk [Internet]. BBC News. 2020 [cited 1 May 2020]. Available from: https://www.bbc.co.uk/news/health-52351290

12. Wu X, Nethery R, Dominici F. A national study on long-term exposure to air pollution and COVID-19 mortality in the United States [Internet]. Projects.iq.harvard.edu. 2020 [cited 1 May 2020]. Available from: https://projects.iq.harvard.edu/covid-pm

13. Duffy B. Life under lockdown: coronavirus in the UK | The Policy Institute [Internet]. Kcl.ac.uk. 2020 [cited 1 May 2020]. Available from: https://www.kcl.ac.uk/news/lifeunder-lockdown-coronavirus-in-the-uk

14. Laker L. Milan announces ambitious scheme to reduce car use after lockdown [Internet]. the Guardian. 2020 [cited 1 May 2020]. Available from: https://www.theguardian.com/world/2020/apr/21/milan-seeks-to-prevent-postcrisis-return-of-traffic-pollution

\section{Additional Resources}

- Chow D. Coronavirus lockdown provides vivid picture of how environment recovers without people [Internet]. NBC News. 2020 [cited 1 May 2020]. Available from: 
https://www.nbcnews.com/science/environment/coronavirus-shutdowns-haveunintended-climate-benefits-n1161921

- Cui Y, Zhang Z, Froines J, Zhao J, Wang H, Yu S et al. Air pollution and case fatality of SARS in the People's Republic of China: an ecologic study. Environmental Health. 2003;2(1).

- Friedman L. New Research Links Air Pollution to Higher Coronavirus Death Rates [Internet]. Nytimes.com. 2020 [cited 1 May 2020]. Available from: https://www.nytimes.com/2020/04/07/climate/air-pollution-coronaviruscovid.html?auth=login-email\&login=email

- Taylor M. Toxic air over London falls by $50 \%$ at busiest traffic spots [Internet]. the Guardian. 2020 [cited 1 May 2020]. Available from:

https://www.theguardian.com/environment/2020/apr/23/toxic-air-over-london-fallsby-50-at-busiest-traffic-spots?CMP=share btn tw

- Wyns A. Climate Change and Infectious Diseases [Internet]. Scientific American Blog Network. 2020 [cited 1 May 2020]. Available from:

https://blogs.scientificamerican.com/observations/climate-change-and-infectiousdiseases/ 